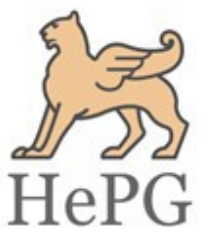

ISSN: 2348-1900

Plant Science Today

http://www.plantsciencetoday.online

\title{
Responses of Rhizophora mangle L. to effluents from textile Industry in Kano, Nigeria
}

\author{
Emmanuel Iwuala, ${ }^{* 1,2}$ Afroz Alam ${ }^{2}$ and Ajiboye Abiodun ${ }^{1}$ \\ ${ }^{1}$ Department of Plant Science and Biotechnology, Federal University, Oye Ekiti, Ekiti State, Nigeria \\ ${ }^{2}$ Department of Bioscience and Biotechnology, Banasthali University, Rajasthan, India
}

Article history

Received: 26 August 2017

Accepted: 09 November 2017

Published: 30 November 2017

(c) Iwuala et al. (2017)

Guest Editor

Manoj S Paul

Publisher

Horizon e-Publishing Group

Correspondence

Emmanuel Iwuala

凶iwuala097@gmail.com

\begin{abstract}
Polluted water discharge sourced from industrial effluent has emerge a distressing happening owing to its harmful effects on health, lives and safety of organisms. The extent of this unpleasant situation by and large remains unidentified. Thus, in the present study, the toxic effects of effluents from textile are analyzed through Rhizophora mangle L., by leaving it to polluted surface water by effluent from the Challawa stream. An observation on the effects of textile effluent polluted water was analyzed on the growth, chlorophyll content, heavy metal quantification and membrane integrity in $R$. mangle was carried out. Seedlings raised from viviparous seeds (propagules) were grown in 50L effluent water from textile industry for 4 weeks. Growth, physiological, biochemical parameters as well as quantification analysis of heavy metals of the seedlings were analysed immediately after the treatment period. The results proved that $R$. mangle seedlings were sensitive to metal toxicity. The treatment significantly reduced the growth index and chlorophyll contents evaluated. MDA content, catalase enzyme and heavy metal content ( $\mathrm{Fe}, \mathrm{Ni}$ and $\mathrm{Cu}$ ) significantly increase when plants were grown in effluent water indicating ROS production. Therefore, this result implies that metals present in the textile effluent induce oxidative stress and membrane damage in $R$. mangle.
\end{abstract}

Keywords: effluent; growth; heavy metal; membrane damage; Rhizophora mangle

\section{Citation}

Iwuala E, Alam A, Abiodun A. Responses of Rhizophora mangle L. to effluents from textile Industry in Kano, Nigeria. Plant Science Today 2017;4(4):202-208. doi: 10.14719/pst.2017.4.4.333

\section{Introduction}

Effluents from industry are inapt products in the era of new technological development. Effluents, basically of chemical origin are frequently released from textile industries in unpredictable quality and quantity. Subsequent to the improper release into the environment, they impair human health and pollute the surroundings. It was also noticed by the World Health Organization and stated that most of the effluents are generated mainly by industries, the extreme sources of pollution (1). Afterwards, Gomez et al. (2) also reported that industries can produce waste materials combined with polluted surface water emanating from the development procedures, which results in unfavourable alterations in physio-chemical, biochemical and biological procedures of certain long-suffering water surfaces.

Industrial waste-waters are particularly chief point sources of potential pollutants. They have 
repeatedly contributed major quantities of BOD, suspended substances, bacteria, heavy metals, and many explicit chemicals potential of causing an extensive jumble of problems in watercourses or downstream utilization. Qualities of wastewater rely on the industry type of the factories. Wastewater released from the food industries contains high BOD.

Conventional procedures such as biological oxygen demand (BOD) and total soluble solids are proving inadequate to find out the type and extent of toxic substances found in a variety of industrial polluted surface waters and recycled waste, routine laboratory assays are not sufficient alone to provide adequate answers on the precise effects of certain substances that are discharged into the environment (3). Consequently, the treated effluents show potential toxicity test and not exceeding the discharge limits (4). Ternes (5) reported that certain chemicals are not permanently removed through the use of the recent technology. Thus, a more toxicity testing procedure is required to remove such toxic substances.

The prominent environmental problems related to several textile industries include, the use of water, its recycling and the disposal of aqueous effluents. For this study, African Mills Industry in Kano, where the effluents are totally emitted through open channels through the Challawa main stream and adversely hinders the health status of the water bodies, and are said to be harmful to aquatic life (6).

In underdeveloped countries, analysis related to toxicity of effluents generated from industry supposes to ascertain that discharges should not have harmful impacts on the immediate environs (7). Nigeria, the Federal Environmental Protection Agency (FEPA) has the mandate to enforce the standard check for pollution management and control of effluents from various industries.

Kano is densely populated and consequently, there are a reasonable number of commercial setups that are spread all over the city, this development increases the risk of pollution that has kept the state under severe threat related to environmental sanity. However, the state of Kano and its ambient environment have experienced consistent degradation of the environment resulting in the reduced bioresources and elimination of organisms out of the location. The majority of the producing companies in Kano State, are known for 'not to treat' their run off water adequately. Therefore, effluents contain some amount of harmful substances and are released adequately in the environment. In Kano, pollutant present in surface waters with notable effluents emerging from several companies is on the increase, as industrial development is on the rise. In Sabo area of Kano, textile industries mark an efficient economic prospect. African textile mills that are situated in Sabo, are renowned for the highly structured production of fibres that gives an identity of a commercial city all over Africa. The process of manufacturing required an enormous amount of water, and after process, majority of toxic water produced is released into the Challawa stream thus, adversely affecting the quality of water. This causes several problems related to toxic effects of this untreated polluted water of industrial origin. Which is of further immediate importance, as a result, some inhabitants of Sabo, receive water supply for household duties and for other relevant importance from these contaminated origins. Furthermore, herdsmen and farmland owners, utilize this water for mixed cropping and cattle grazing hence an issue of biomagnifications also comes in this context. Conclusively, it is a known fact that toxic substances from the polluted water hinder plant growth, affect food production along with other harmful effects on the population. However, to assess the exact scenario, there is a need of proper and feasible methods to check the pollution level. Therefore, this study is done to determine the severity of toxicity from those effluents that arrived into the water body from the textile industry using Rhizophora mangle L., the red mangrove.

\section{Materials and Methods \\ Treatment during plant growth}

Water samples were sourced from two major locations in Duro river, Chalawa and Kano into containers of clean plastic. Location one is the area in which the effluent is discharged into the stream, location two was $50 \mathrm{~m}$ upstream from the discharge point and serve as control. Physicochemical variables from the sample of water collected was analysed.

Adequate propagules of $R$. mangle were obtained from Majidun area of Lagos Lagoon, Nigeria in a single group. Seedlings grew on the nylon beds for 21 days to grown up to the height of $7 \mathrm{~cm}$. At this stage they were subsequently transferred into a plastic bowls having a proportionate ratio of both loam and sandy soils. One seedling sowed in each bowl and each seedling was kept as one stand. The bowls that held the seedling were kept in a greenhouse chamber at the University of Lagos. Consequently, 1L water sample with effluent was applied as treatment at every $3^{\text {rd }}$ day, for a duration of 4 weeks. A control was also maintained with uncontaminated water. Towards the very end of the treatment duration the plants were uprooted for the subsequent morphological and biochemical analysis.

\section{Measurement of Plant growth}

Roots and shoots of harvested plants were initially cleaned with fresh water, then the length of both was taken according to the method of Guo et al. (8). 


\section{Determination of Dry weight biomass}

Uprooted plants were vigorously washed with clean running tap water for proper removal of soil particles, etc. Afterwards, they were placed in labelled brown paper bags and dried at $80^{\circ} \mathrm{C}$ for 72h. Subsequently. they were weight using a weighing balance (Mettler AE 100) to quantify their biomass (8).

\section{Measurement of total chlorophyll pigments}

For estimation of total chlorophyll, the leaves of treated and controlled seedlings were extracted in $80 \%$ acetone by homogenizing in an autoclaved pestle and mortar. The homogenate material was centrifuged at $3000 \mathrm{rpm}$ for $10 \mathrm{~min}$, at $4^{\circ} \mathrm{C}$. The supernatants were read at 480, 645 and $663 \mathrm{~nm}$ absorbance. The calculation was done according to following formula given by Arnon (9):

Total chl $(a$ and $b)(\mathrm{mg} / \mathrm{L})=20.2\left(\mathrm{~A}_{645}\right)+8.02\left(\mathrm{~A}_{663}\right)$

\section{Estimation of lipid peroxidation}

This was measured according to the protocol proposed by Alia et al. (10), by determining the concentration of malondialdehyde (MDA) with thiobarbituric acid (TBA). The leaves and the roots were grounded in $1 \%(\mathrm{w} / \mathrm{v})$ trichloroacetic acid (TCA) and centrifuged. Then, $20 \%$ in $4 \mathrm{ml}$ of TCA containing $0.5 \%(\mathrm{w} / \mathrm{v}) \mathrm{TBA}$ was added to equal $1 \mathrm{ml}$ of supernatant. The mixture was incubated at $95^{\circ} \mathrm{C}$ for $30 \mathrm{~min}$. Subsequently, the absorbance, at 532 $\mathrm{nm}$ and $600 \mathrm{~nm}$ was estimated, and 120 extinction coefficient of $155 \mathrm{mM}$ per $\mathrm{cm}$ were used to calculate the concentration of MDA.

\section{Concentration of metal content}

The measurement for $\mathrm{Cu}$, Fe and $\mathrm{Ni}$ was quantified using an Atomic Absorption Spectrophotometer (AAS) (ThermoScientific ICE 3000), according to the procedure of Isaac and Kerber (11). Harvested root samples were first cleaned with uncontaminated water and then dried through blotting using a Whatman filter paper. Afterwards, samples were dried using a typical temperature of $80^{\circ} \mathrm{C}$ for 3 days. Subsequently, $100 \mathrm{mg}$ sample was taken and digested for 4 hours at $480^{\circ} \mathrm{C}$, followed by the addition of $2 \mathrm{ml}$ of $5 \mathrm{M}$ nitric acid $\left(\mathrm{HNO}_{3}\right)$ to the digested sample. It was left on a sand bath for evaporation till dryness. Finally, the substance was heated at $15 \mathrm{~min}$ for $40^{\circ} \mathrm{C}$. The residue added to 2 $\mathrm{ml}$ of concentrated $\mathrm{HCl}$ and Whatman filter paper no. 42 was used to filter the remaining solution.

\section{Enzyme extraction and assays}

The activity of Catalase (CAT) was measured by the method of Aebi (12). $3.0 \mathrm{ml}$ of the assay was mixed with enzyme extract $100 \mu \mathrm{l}, \mathrm{H}_{2} \mathrm{O}_{2}(300 \mathrm{mM}) 100 \mu \mathrm{l}$, phosphate buffer $2.8 \mathrm{ml}(50 \mathrm{mM})$ and with EDTA $(2 \mathrm{mM}) \quad(\mathrm{pH}$ 7.0). Catalase concentration was measured by observing the reduction at $240 \mathrm{~nm}$ absorbance value owing to $\mathrm{H}_{2} \mathrm{O}_{2}$ disappearance.

\section{Results \\ Characteristics of physicochemical parameters of water sample}

Table 1 depicts the variables of samples of water in comparison with limit values accepted by a standard enforcing authority Federal Environmental Protection Agency in Nigeria. Parameters like BOD, $\mathrm{Cu}, \mathrm{Cr}$, $\mathrm{Zn}$ and Ni levels were significantly higher than the preferred recommended standards, thereby exceeding the reference limits of discharge. Obtained results for $\mathrm{pH}$ value were $8.46 \mathrm{mg} / \mathrm{L}$, for COD (138.75 mg/L), copper content $(17.73 \mathrm{mg} / \mathrm{L})$, and total suspended mean results of $54.3 \mathrm{mg} / \mathrm{L}$ was found significantly higher than the FEPA values.

Table 1. Comparison of physico-chemical properties of effluent water collected from a textile fabric industry in Challawa stream from Kano state in comparison with FEPA standards.

\begin{tabular}{|c|c|c|c|}
\hline $\begin{array}{l}\text { Sl } \\
\text { No. }\end{array}$ & Parameters & $\begin{array}{l}\text { Mean levels } \\
\text { detected }\end{array}$ & $\begin{array}{c}\text { FEPA } \\
\text { standards }\end{array}$ \\
\hline 1 & $\mathrm{pH}$ & 8.46 & $6-9$ \\
\hline 2 & Turbidity (FTU) & 69.25 & - \\
\hline 3 & $\begin{array}{l}\text { Conductivity } \\
(\mu \mathrm{s} / \mathrm{cm})\end{array}$ & 1677.3 & 7000 \\
\hline 4 & TDS & 821 & 2000 \\
\hline 5 & TSS & 54.3 & 40 \\
\hline 6 & $\mathrm{Cl}-$ & 65.5 & 500 \\
\hline 7 & $\mathrm{SO}_{4}^{2-}$ & 15.50 & 300 \\
\hline 8 & $\mathrm{NO}_{3^{-}}$ & 21.27 & 20 \\
\hline 9 & $\mathrm{NH}_{3}^{-}$ & 0.21 & 4.0 \\
\hline 10 & $\mathrm{CN}^{-}$ & 5.03 & 0.05 \\
\hline 11 & $\mathrm{PO}_{4}^{3-}$ & 5.37 & 5.0 \\
\hline 12 & BOD5 & 64.25 & 40 \\
\hline 13 & COD & 138.75 & 200 \\
\hline 14 & $\mathrm{Cu}$ & 17.73 & 0.2 \\
\hline 15 & $\mathrm{Zn}$ & 54.71 & 2.0 \\
\hline 16 & $\mathrm{~Pb}$ & 0.08 & 0.1 \\
\hline 17 & $\mathrm{Cr}$ & 3.04 & 0.1 \\
\hline 18 & $\mathrm{Ni}$ & 1.24 & 0.2 \\
\hline
\end{tabular}

The nitrate, sulphate and phosphate were found within the normal specification. The nitrate level ranged from 21.0 to $20 \mathrm{mg} / \mathrm{L}$, the sulphate 

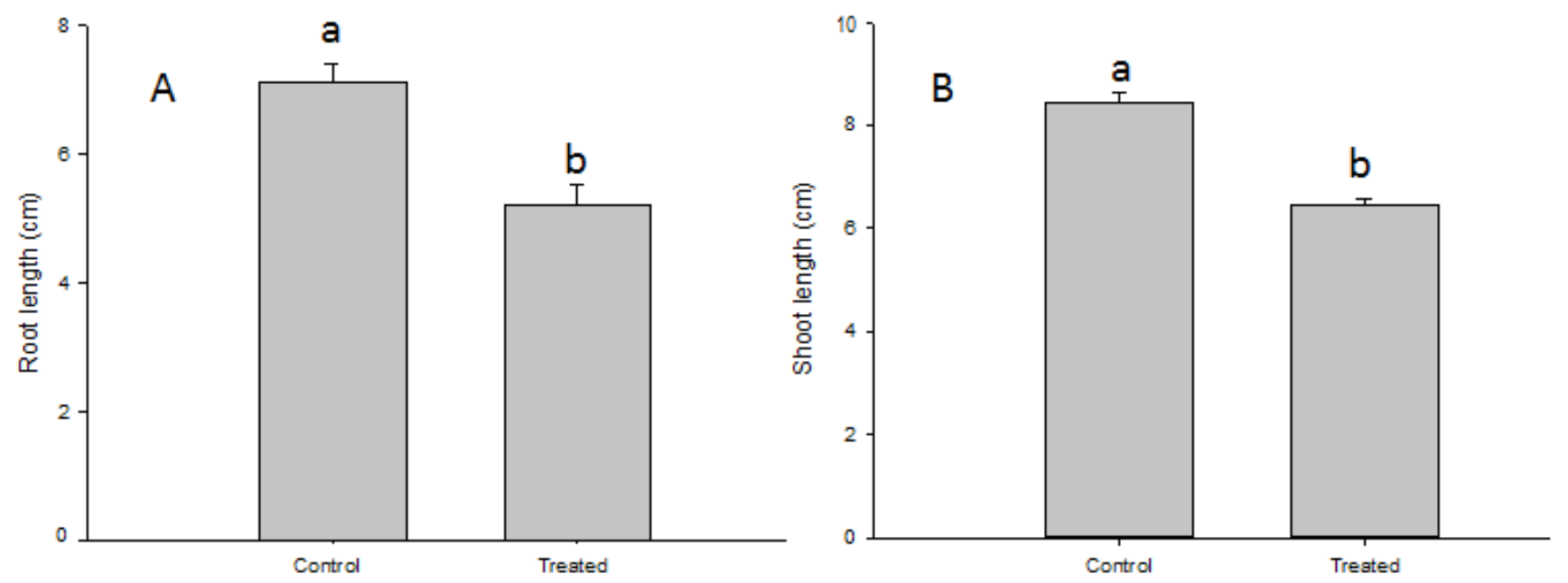

Figure 1. Changes of effluent treatment on the (A) root (B) shoot length of Rhizophora mangle. Data are the results of three mean \pm SE using one way ANOVA at $p<0.05$.

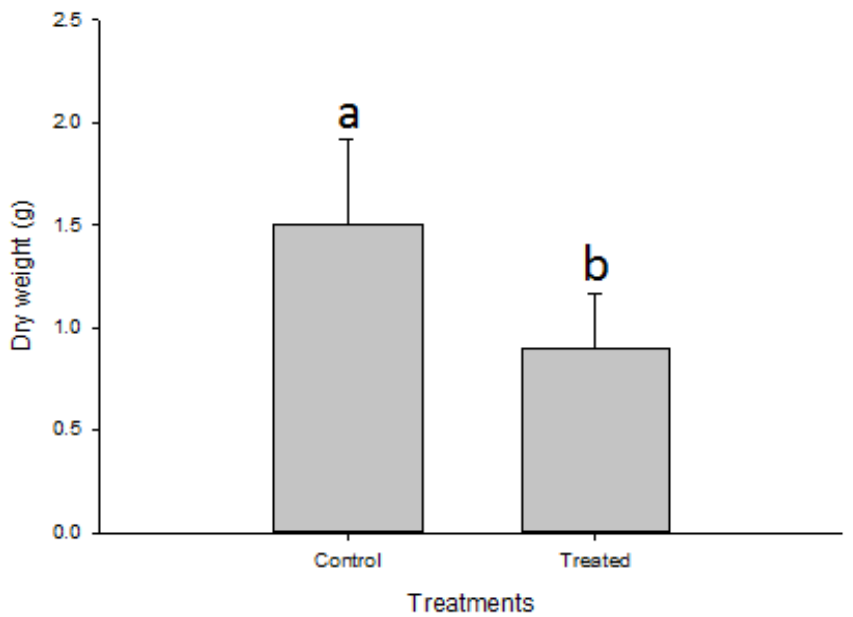

Figure 2. Changes of effluent on the dry weight of Rhizophora mangle. Data are the results of three mean \pm SE using one way ANOVA at $p<0.05$

ranged from $65.0-500 \mathrm{mg} / \mathrm{L}$ and the phosphate range from 5.37 to $5.0 \mathrm{mg} / \mathrm{L}$. High levels of these parameters, especially nitrate and phosphate in a receiving body of water environment leads to nutrient build-up (eutrophication) which possess a serious problem in lakes and slow moving waters.

The responses to the effluent treatment on the root and shoot length of $R$. mangle is given in Figure 1 . The root length of $R$. mangle was remarkable reduced by the effect of the textile effluent. After the treatment period, the control showed a root and shoot length mean value of $7.11 \pm 0.31 \mathrm{~cm}$ and $8.12 \pm 0.22 \mathrm{~cm}$ unlike the plants reacted with effluent that had a reduced difference in mean found significant at $p<0.05$ with a mean value of $5.21 \pm 0.33$ and $6.2 \pm 0.11 \mathrm{~cm}$.

The dry weight biomass data showed a pronounced difference that treated effluent had hindering changes on $R$. mangle, since the plants were exposed to effluent accumulated reduced biomass in contrast to their control plants (Figure

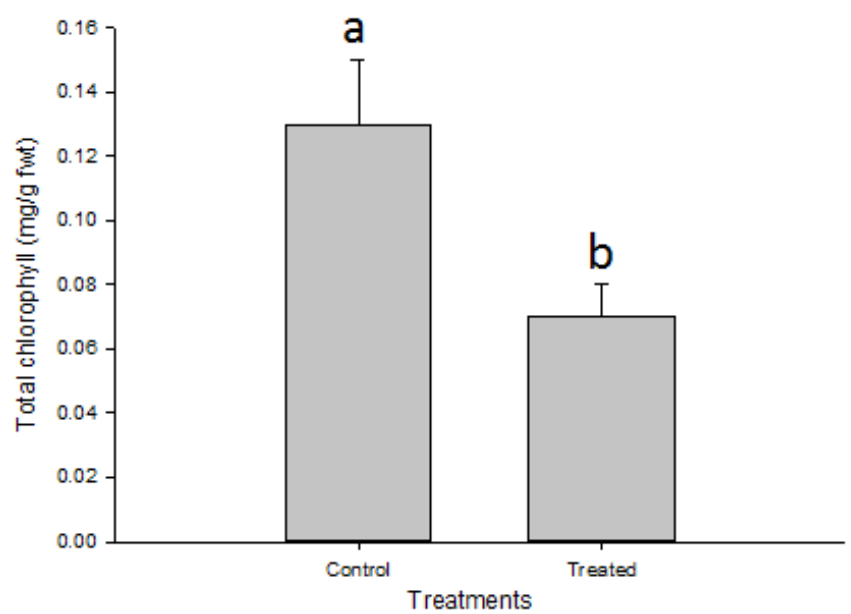

Figure 3. Changes of effluent on the chlorophyll pigments of Rhizophora mangle. Data are the results of three mean \pm SE using one way ANOVA at $p<0.05$

2). The effluent caused $42 \%$ growth length reduction in $R$. mangle as different to the control plants.

The total chlorophyll pigments presented showed a remarkable inhibitory effect on $R$. mangle as effluents accumulated on plants reduced photosynthetic pigment in contrast to their controlled \& well watered plants (Figure 3). Plant exposed with treated effluent showed reduction in growth and length compared the control plants.

MDA contents as seen in leaves and roots showed a significant increase (Figure 4). In leaves, MDA contents in $R$. mangle treated plants exposed to effluents increased significantly by $42 \%$ as compared to the control plants. While in roots, MDA increased in the treated plant by $63 \%$ and for the control 26\%, respectively. Effluent had a pronounced increase significantly in CAT activity assessed in roots and leaves (Figure 5) in comparison to its control. 


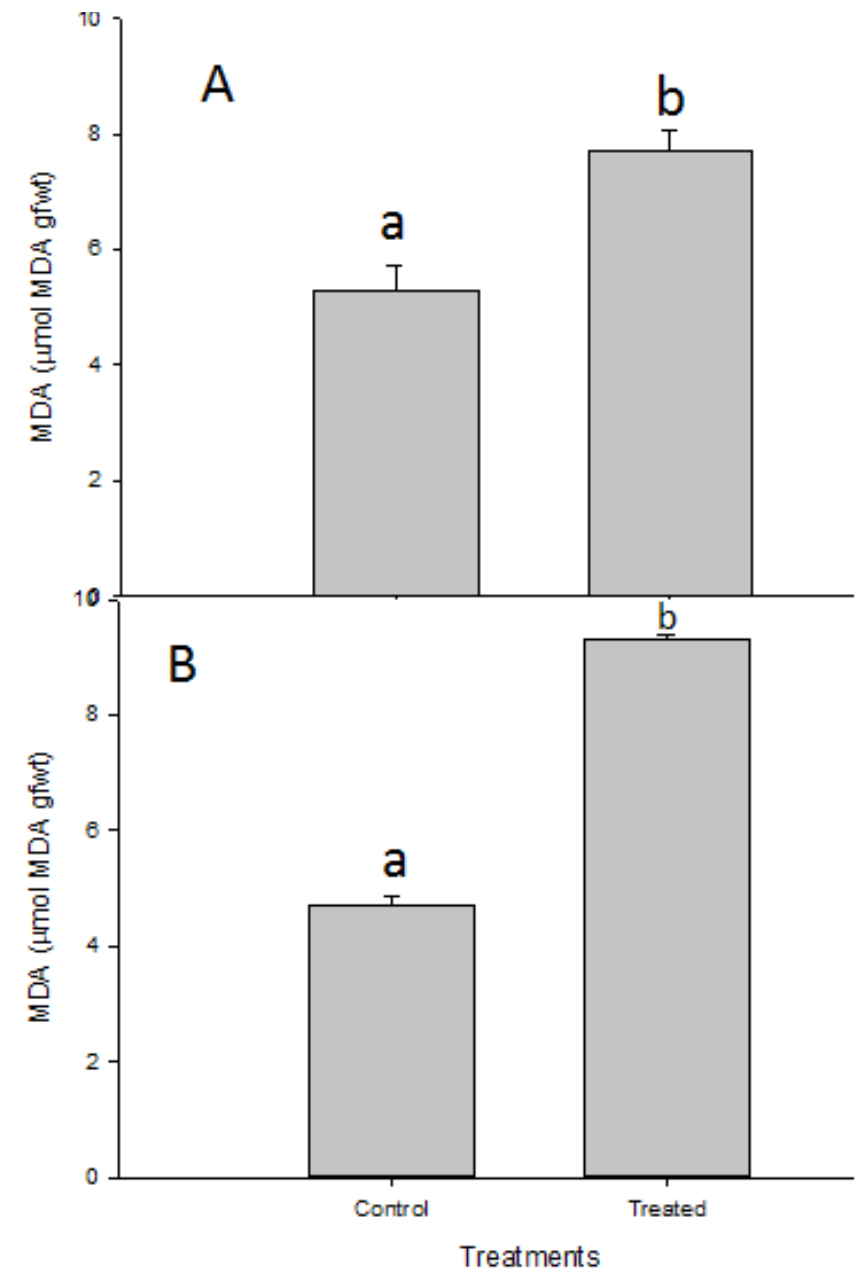

Figure 4. Changes in MDA contents (A) leaves (B) root of Rhizophora mangle. Data are the results of three mean \pm SE using one way ANOVA at $p<0.05$

The interaction of this plant species with effluent showed a significant reduction in nutrient uptake by roots. Treated plants were significantly $(p<0.05)$ lower as compared to its control. $\mathrm{Cu}, \mathrm{Fe}$ and Ni concentration were significantly higher in roots of $R$. mangle with value of 63,71 and $74 \%$ in comparison to its control value of 10,11 and $8 \%$ respectively (Figure 6)

\section{Discussion}

This study examined how effluents affected the growth, dry weight, photosynthetic pigment, MDA content and catalase activity in $R$. mangle. The obtained results showed that the effluents in Challawa river are capable of causing biological toxic effects on flora and fauna. Reduced length and growth in plants similarly is reported in wheat crop (13) and maize (14). This is responsible because of the metal content present in the effluent water, similar results were reported by Odjegba and Bamgbose (15). The reduced growth could be due to the hindrances and imbalances of accumulation of metals. For accuracy, we tested the physio-chemical properties of the treated effluents. The low chlorophyll content observed in

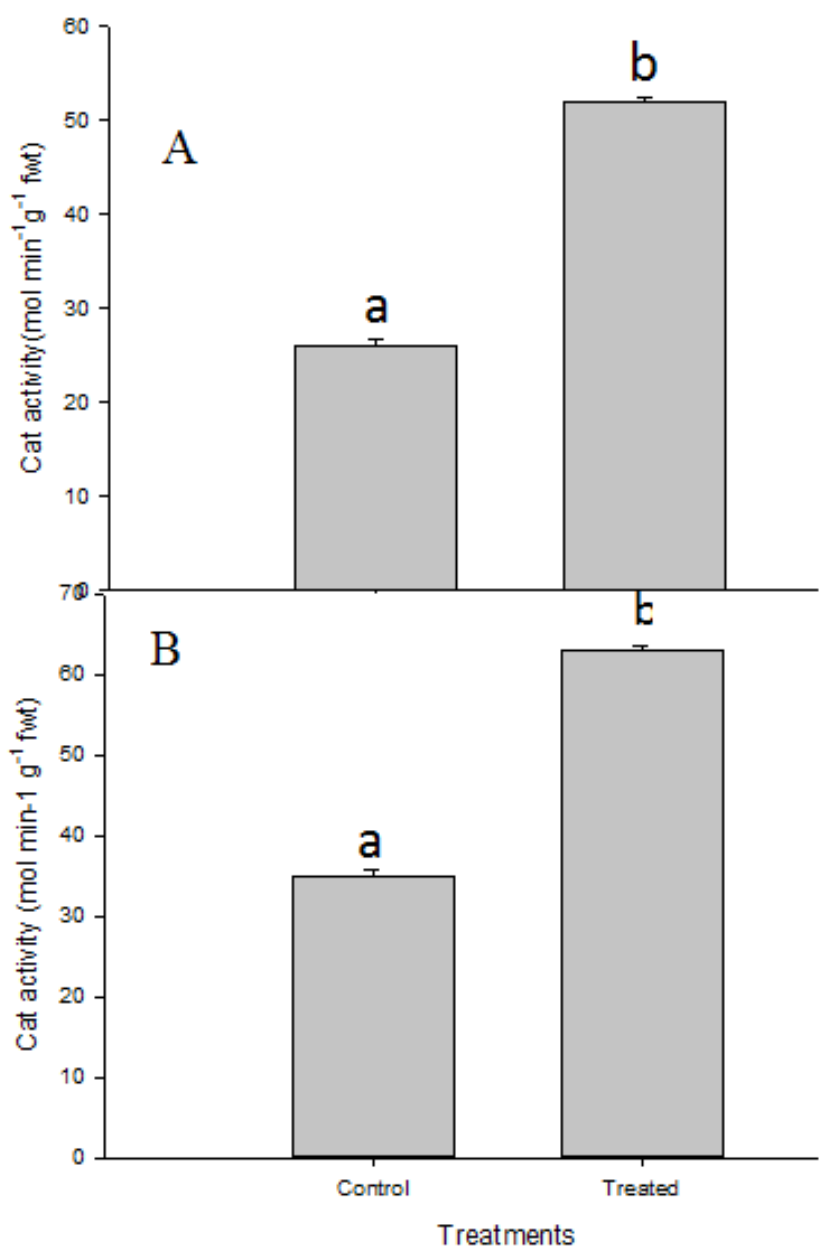

Figure 5. Changes in Catalase activity (A) leaves (B) root of Rhizophora mangle. Data are the results of three mean \pm SE using one way ANOVA at $p<0.05$

the leaves of effluent treated seedlings of $R$. mangle could be due to the heavy metal deposit that negatively affected the pigments. Murch et al. (16) reported that net photosynthesis decreases in variously stressed plants, such as heavy metals, salinity and drought. It is shown that a significant amount in concentrations of $\mathrm{Cu}, \mathrm{Zn}, \mathrm{Cr}, \mathrm{CN}$ and $\mathrm{Ni}$ were present likewise, TSS, $\mathrm{PO}_{4}{ }^{3-}$ and $\mathrm{BOD}$ were high above the supposed standard limits. The high concentrations of COD implies toxic conditions and signify the presence of biological toxic substances This is in agreement with the reports by Onwordi and Dan-Sulaiman (17) and Acworth and Bailey (18) that heavy metal under stress produce free radicals in excess. An efficient characteristics of metal-induced environmental stress is associated to the release of a singlet oxygen ROS in living organs of the affected organism as seen in some previous studies (19-21). Generally, quantification of lipid content in any organism is an indicator of the effects of ROS under abiotic stress. As, Halliwell and Gutteridge (22) also reported as a recommended marked index for concentration degree of ROS and membrane damage. Investigations were also carried on the 
concentration of MDA contents by determining its concentration in the leaves and root of the plant.
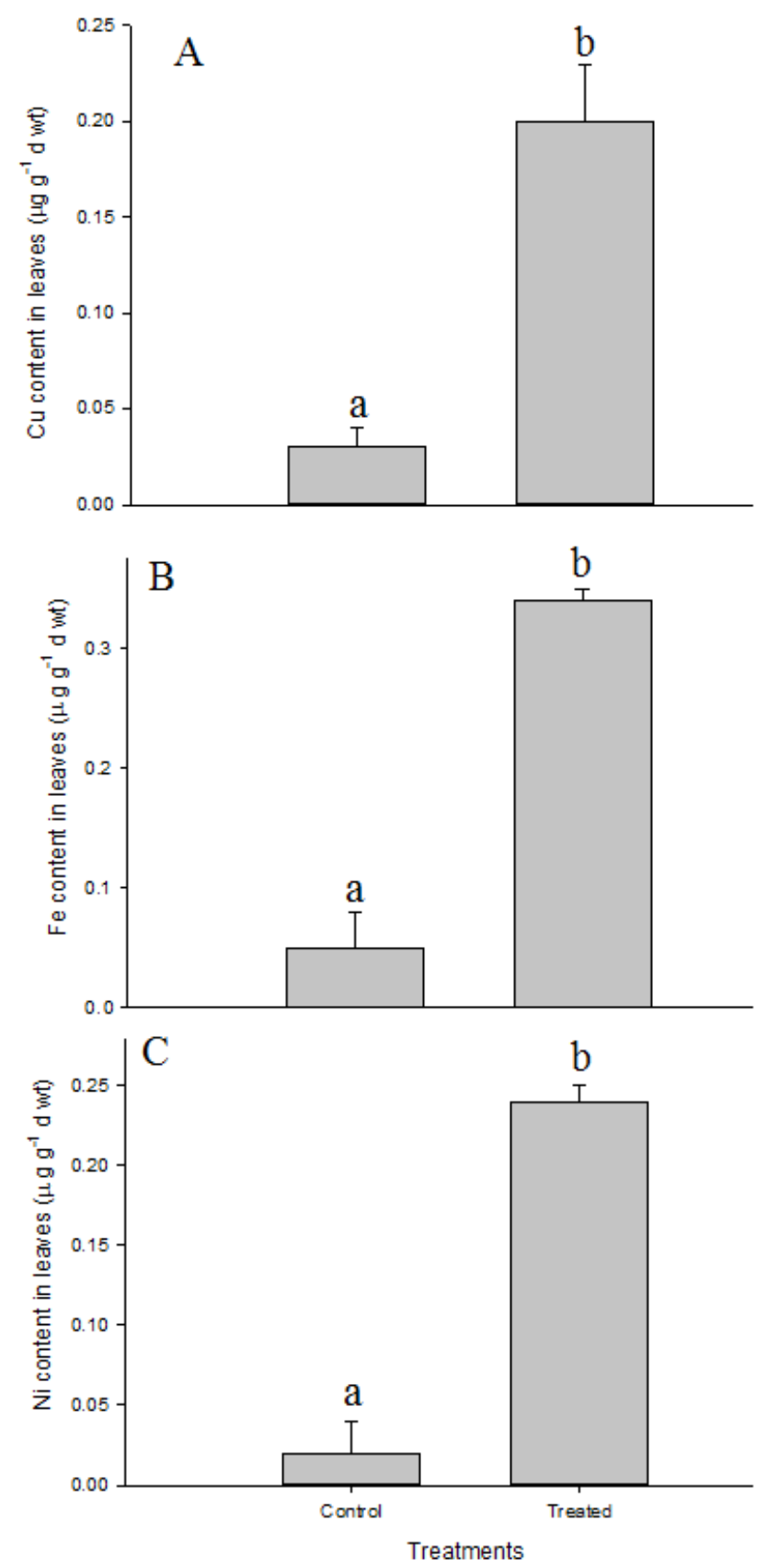

Figure 6. Heavy metal content in (A) $\mathrm{Cu}$ (B) Fe (C) $\mathrm{Ni}$ of Rhizophora mangle. Data are the results of three mean \pm SE using one way ANOVA at $p<0.05$

$R$. mangle when treated with effluent rich textile water sample displayed a significant high concentration of MDA. This may be a reason that plants accumulated metals from the effluents thereby enhanced the production of numerous ROS, thus, causing marked oxidative stress. These results are similar to previous results from on Bruguiera gymnorrhiza (23) and Celosia argentae (15). The concentration of catalase was reported higher in the textile treated plant both in roots and leaves as compared to the plant under well watered conditions. This is in conformity with result reported for Triticum aestivum (24). A result of increased catalase activity had also been found under stress in Brassica juncea (25, 26). Experiment on contaminants found in natural water bodies are of emerging relevance because these water bodies are depended upon for agricultural and domestic purposes, especially in this experimental site where the depend on the use of the river water for drinking purposes for animals, laundry and household activities. This study has well demonstrated that water should be checked and quality control precisely enforced for the proper regulation so that effluents from industries for secure use should be directly discharged in crop production and other household water usage.

\section{Acknowledgements}

One of the authors (EI) is grateful to Mr. Begusa, Dept. of Chemistry, University of Lagos, Nigeria.

\section{Conflict of Interest}

The authors have no conflict of interest.

\section{Authors' Contribution}

EI conducted the whole experiment following collection of data. AA done statistical analysis and drafted the manuscript with collection of references. EI and AA hypothesised, designed the experiment, discussed the findings with scientific justification and over all written the whole manuscript.

\section{References}

1. WHO. 2002. Water Pollutants, Biological Agents, Dissolved Chemicals, Non-dissolved Chemicals, Sediments, Heat, WHO CEHA, and Amman, Jordan.

2. Gomez N, Sierra MV, Cortelezzi Rodrigues A, Capitulo A. Effects of discharges from the textile industry on the biotic integrity of benthic assemblages. Ecotoxicology and Environmental Safety 2008; 69: 472-479. doi: 10.1016/j.ecoenv.2007.03.007

3. Sacan MT, Balcioglu IA. A case study on algal response to raw and treated effluents from an aluminum plating plant and a pharmaceutical plant. Ecotoxicology and Environmental Safety 2006; 64: 234-243. doi: 10.1016/j.ecoenv.2005.03.017

4. Lin CF, Hao OJ, Jeng FT. Microtox evaluation of industrial wastewaters. Water Science and Technology 1994; 30: 97-106.

5. Ternes TA. Occurrence of drugs in German sewage treatment plants and rivers. Water Research 1998; 32:3245-3260. doi: 10.1016/S0043-1354(98)00099-2

6. Odjegba JV, Bamgbose NM. Toxicity assessment of treated effluents from a textile industry in Lagos, Nigeria. African Journal of Environmental Science and Technology 2012; 6(11): 438-445. doi: 10.5897/AJEST12.133

7. Whitehouse P, Dijk P. The precision of aquatic toxicity tests: the implications for the control of effluents by direct toxicity assessment. In: Tapp JF, 
Wharfe JR, Hunt SM (eds), Toxic Impacts of Wastes on the Aquatic Environment. Cambridge; 1996.

8. Guo J, Yang Y, Wang G, Yang L, Sun X. Ecophysiological responses of Abiesfabri seedlings to drought stress and nitrogen supply. Physiologia Plantarum 2010; 139: 335-347

9. Arnon DI. Copper enzymes in isolated chloroplast, polyphenol-oxidase in Beta vulgaris. Plant Physiology 1949; 24: 1-15. doi: 10.1104/pp.24.1.1

10. Alia KV, Prasad SK, Pardha SP. Effect of zinc on free radical and proline in Brassica juncea and Cajanus cajan. Phytochemistry 1995; 39: 45-47. doi: 10.1016/0031-9422(94)00919-K

11. Isaac RA, Kerber JD. Atomic absorption and flame photometry techniques and uses in soil, plant and water analysis. In: Instrumental Methods for Analysis of Soils and Plant Tissue, ed. L. M. Walsh, Madison, WI: SSSA. 1971. p. 17-37.

12. Aebi H. Catalase in vitro. Methods in Enzymology 1984; 105: 121-126. doi: 10.1016/S00766879(84)05016-3

13. Khan TI, Jain V. Effect of textile industry waste water on the growth and some biochemical parameters on Triticum aestivum. Journal of Environment Pollution 1995; 2: 47-50.

14. Pandey SN, Nautiyal BD, Sharma CP. Pollution level in distillery effluent and its phytotoxic effect on seed germination and early growth of maize and rice. Journal of Environmental Biology 2008; 29: 267-270.

15. Odjegba J, Adeniyi M. Responses of Celosia argentea L. to simulated drought and exogenous salicylic acid. Nature and Science 2012; 10(12): 2-6.

16. Murch SJ, Haq K, Rupasinghe VHP, Saxena PK. Nickel contamination growth and secondary metabolite composition of St. Johns Wort (Hypericum perforatum L.). Environmental and Experimental Botany 2003; 49: 251-257. doi: 10.1016/S0098-8472(02)00090-4

17. Onwordi CT, Dan-Sulaiman SB. Physico-chemical characterization and heavy metals of effluents from glass processing plant in Agbara Industrial Estate, Ogun, Nigeria Archives of Applied Science Research 2010; 2(1): 212-217.
18. Acworth IN, Bailey B. Reactive oxygen species. In: Acworth, IN and B. Bailey (eds). The handbook of oxidative metabolism. ESA Inc., Massachusetts. 1997. p. 1-4.

19. Mishra A, Choudhuri MA. Effects of salicylic acid on heavy metal-induced membrane deterioration mediated by lipoxygenase in rice. Biologia Plantarum. 1999; 42: 409-415. doi: 10.1023/A:1002469303670

20. Wang YS, Wang J, Yang ZM, Wang QY, Li B, Li SQ, $\mathrm{Lu}$ YP, Wang SH, Sun X. Salicylic acid modulates aluminum-induced oxidative stress in roots of Cassia tora. Acta Botanica Sinica 2004; 46: 816828.

21. Shi Q, Zhu Z. Effects of exogenous salicylic acid on manganese toxicity, element contents and ant oxidative system in cucumber. Environmental and Experimental Botany 2008; 63: 317-326. doi: 10.1016/j.envexpbot.2007.11.003

22. Halliwell B, Gutteridge JMC. Free Radicals in Biology and Medicine 3rd ed. Oxford Science Publications, New York. 1999. p. 936.

23. Zhang F, Wang Z, Dong J. Effect of heavy metal stress on antioxidative enzymes and lipid peroxidation in leaves and roots of two mangrove plant seedlings (Kandelia candel and Bruguira gymnorrhiza). Chemosphere 2007; 67: 44-50. doi: 10.1016/j.chemosphere.2006.10.007

24. Sharma V, Parmar P, Kumari N. Differential cadmium stress tolerance in wheat genotypes under mycorrhizal association. Journal of Plant Nutrition 2016; 36(4): 1-12. doi: 10.1080/01904167.2016.1170851

25. Sairam RK, Tyagi A. Physiology and molecular biology of salinity stress tolerance in plants. Current Science 2004; 86: 407-421

26. Mittal S, Kumari N, Sharma V. Differential response of salt stress on Brassica juncea; Photosynthetic performance, Protein, Proline, D1 and antioxidant enzymes. Journal of plant biochemistry \& physiology 2012; 4: $17-26$ doi: 10.1016/j.plaphy.2012.02.003 